Slawoj Szynkiewicz

\section{NIE WSTYDŹMY SIĘ RELATYWIZMU}

Mahathir bin Mohamad zatrzymał się o krok przed nazwaniem koncepcji praw człowieka przejawem współczesnego imperializmu. Być może przekroczyłby tę granicę gdyby pisał swoje słowa po wojnie NATO z Serbią, pierwszej dla której pretekstem stały się owe prawa. Formalne powody, dla których tradycyjnie przystępowano do wojen bywały z reguły szlachetne żądanie szacunku dla osoby panującej, dla narodu, czy też interes tego ostatniego. Prawa człowieka są uogólnionym interesem narodu i wojnę w ich imieniu można przedstawić jako usprawiedliwioną, nawet jeśli przyniesie ona owemu narodowi więcej nieszczęść niż przeżył on przed jej wybuchem. Tak zresztą było z Albańczykami, których wymordowano dziesięciokrotnie więcej podczas nalotów na Jugosławię niż na wcześniejszym etapie wojny domowej.

Pojęcie wartości azjatyckich nie jest ostre, ani też nie można go odnieść do całej Azji. Podobnie jest z prawami człowieka, utożsamianymi z wartościami zachodnimi. Dodaje się do nich nowe, inne usuwa lub przenosi na pozycje drugorzędne, prawa grupowe umieszcza wśród indywidualnych (porównaj odrzucenie czystek etnicznych), ograniczając w ten sposób miejsce jednostki na rzecz społeczeństwa. Jesteśmy świadkami cyzelowania dopiero samej koncepcji. Trudno się temu dziwić, skoro jest ona nowa, mimo iż jej źródeł upatruje się u korzeni cywilizacji europejskiej.

Nowość koncepcji nie przeszkadza głoszeniu tezy, iż prawa człowieka są uniwersalne, a tym samym niejako wyższej rangi niż regionalne, w tym wypadku azjatyckie. Poglądowi temu przeciwstawia się tezę, że różne społeczeństwa wyznawać mogą odmienne wartości, wynikające $\mathrm{z}$ własnej tradycji. $\mathrm{W}$ tym sensie prawa człowieka są również regionalne, właściwe pewnej grupie społeczeństw euro-amerykańskich o wspólnym podłożu kulturowym. Zamierzam zatrzymać się nad kwestią prawomocności stosowania $\mathrm{w}$ tym kontekście podejścia zwanego relatywizmem kulturowym. Uprzedzając wniosek, powiem że uważam je za usprawiedliwione. 
Przeciwnicy tego podejścia utożsamiają je $\mathrm{z}$ relatywizmem moralnym, co ma brzmieć jak zarzut, ale byłby nim tylko wówczas gdybyśmy rozumieli go jako podwójny standard ocen ferowanych w ramach jednego systemu wartości i wobec podobnych zjawisk. Zdarza się to zresztą dość często. Natomiast odmienne systemy wartości sa $\mathrm{z}$ reguły odmiennie warunkowane $\mathrm{i}$ uzasadniane specyficznym kodem ideologicznym, a ich normy nie są porównywalne pod względem treści i zakresu przedmiotowego. Nikt nie twierdzi, że wszyscy ludzie wyznają te same wartości, chociaż można utrzymywać, że są one do siebie zbliżone. Nawet w takim wypadku inaczej rozkładają one akcenty, inaczej też kształtują hierarchię poszczególnych wartości, których lista może się składać z identycznych lub nieco zmienionych pozycji. Wskazuje na to premier Mahathir cytujac badania Davida Hitchcock'a.

Często wysuwa się demagogiczny argument, że tortury dręczą jednakowo pod każdą szerokością geograficzną, więc nie ma tu miejsca na relatywizację. Tymczasem tam, gdzie wprowadzono ich zakaz, dotyczy on samej instytucji tortur i nie oznacza zakazu zadawania cierpienia w dowolnej sytuacji. Jest faktem, że wszystkie kultury ludzkie negatywnie oceniają zabójstwo, ale dopuszczają pozbawianie życia i często dręczenie fizyczne w imieniu prawa lub dla dobra ogólnego. W czasie wojny wietnamskiej Amerykanie gorszyli się brutalnym zachowaniem swoich wietnamskich i południowokoreańskich sojuszników, dopuszczonym przez ich normy zwyczajowe. Jednakże dowództwo amerykanskie nie interweniowało $w$ tych kwestiach i stosowało odpowiedzialność za podobne czyny jedynie wobec własnych żołnierzy i tylko wybiórczo.

Nie twierdze, że torturowanie należy chronić tylko z tego powodu, że jest ono gdzieś zwyczajowo przyjęte, zwracam jednak uwagę na to, że tolerowanie go może wynikać nie $\mathrm{z}$ tzw. upadku moralności, ale z odmiennego niż europejski stosunku do życia ludzkiego. Pojmowane ono bywa jako wartość przemijajaca i powracająca (reinkarnacja), podporzadkowana dobru grupy (porzucanie chorych i starców przez nomadów-łowców, ,złożenie na ołtarzu ojczyzny"), transcendentna (oczywistość życia pozagrobowego, porównywalnego z doczesnym) lub honorowa wreszcie (samobójstwo rytualne). W takich warunkach pozbawiania życia innych i siebie lub ryzykowania nim nie postrzega się jako czynności bezwarunkowo nagannej. Dodać można, że podobne konotacje były powszechne m.in. w tradycyjnej kulturze ludów Syberii i Dalekiego Wschodu. Po cześci przynajmniej tłumacza one zachowania Japończyków wobec jeńców podczas II wojny światowej albo (przesadne zresztą) raporty kronikarskie o okrucieństwach Mongołów w czasach Czyngischana.

Tortury fizyczne stały się ulubionym hasłem rozpoznawczym co radykalniejszych obrońców praw człowieka w zachodnim rozumieniu.
Przykładem tego jest pewien autor pisujacy $\mathrm{w}$ jednym $\mathrm{z}$ centralnych dzienników polskich. Nie przypominam sobie takiego tekstu, w którym zrezygnowałby on z przyjemności odwoływania się do tortur.

Z kolei, w kulturze Zachodu popularne stały się tortury psychiczne, czyli dręczenie obrazami okrucieństw wypełniających komiksy dziecięce i popularną twórczość medialną dla dorosłych. Ta kaleka wersja rozważań nad tragizmem losu ludzkiego, będących budulcem sztuki europejskiej od czasów antycznych, stała się swoistym przemysłem eksploatującym motywy krwawe i bestialskie. Przynosza one dyskomfort ich odbiorcom, choć u cześci z nich zaspokajają potrzebę krwiożerczości i kształcą postawy brutalne. Dominacja zła katastrofizmu charakteryzuje media zachodnie najprawdopodobniej za przyczyną judeo-chrześcijańskiej koncepcji totalnej kary, apokalipsy, którą na co dzień zastępują tragedie w miniaturze.

Oczekiwanie końca świata to specjalność ludzi Zachodu. W Azji nikt nie zwrócił uwagi na przepowiednie Nostradamusa, nie przyjął się też katastrofizm milenijny. Nie powstawały tam wizje ostatecznego krachu ani nie zajmowano się obliczaniem daty, kiedy miałby on nastąpić. Azjatyckie sekty, które krzewią motyw katastrofy, działaja z reguły w świecie zachodnim, swoistym wyjątkiem była głośna ostatnio sekta Falun Gong. W ich ujęciu krach nie jest postrzegany totalnie, lecz jawi się jako rewolucyjne zerwanie $z$ ,dotychczasowym porzadkiem, znamionuje przełom i poczatek nowego etapu. Dzieje się tak za przyczyną różnych koncepcji czasu — linearnej lub cyklicznej — dominujących w podświadomych kategoryzacjach właściwych ludziom Zachodu i Wschodu.

Brak szacunku dla cudzych zwyczajów i wartości zbyt często pojawia się w naszej kulturze, co powinno stać się przedmiotem niepokoju moralnego. Znajduje to wyraz m.in. w bezkrytycznym poszerzaniu katalogu praw człowieka na przekór ich uniwersalnemu ideałowi. Pojawiły się w nich takie na przykład „wartości" jak prawo do prywatności i prawo własności ${ }^{1}$. Absurdalność tego pierwszego jest oczywista dla każdego, kto choćby pobieżnie zetknął się z kulturami pozaeuropejskimi. Co zaś tyczy własności, to etnocentryzm autorów nie pozwolił im dopisać „prywatnej", o która w danym wypadku chodzi. Innej bowiem nie znają, choć dla wielu ludzi na świecie ważniejsza jest własność wspólnotowa. Występujące i u nas obawy przed „wykupieniem" nie sa obce państwom jeszcze biedniejszym, w których wiadomo, że liczenie na filantropię światowych koncernów jest iluzją, a owa pozorna wartość własności zdaje się działać na ich rzecz.

Pod znakiem zapytania stoi też typowa dla liberalnej tradycji myślenia pierwszoplanowość interesów jednostki przed społecznymi. Temat jest

${ }^{1}$ E L. E. Sponsel, „Human right and advocacy anthropology", w: Encyclopedia of cultural anthropology, eds: D. Levinson, M. Ember, New York 1996, Henry \& Co., t. 2, s. 602-607. 
zbyt obszerny, by go tu podejmować, odwołam się więc do wątpliwości podniesionych przez Z. Baumana ${ }^{2}$. Odróżnia on status ,,jednostki de jure ${ }^{2}$ od ,jednostki de facto", ten ostatni zaś kształtuje się w procesie rozwoju indywidualnego w ścisłym związku z otoczeniem. Prawa człowieka zdają się interesować tylko pierwszym $\mathrm{z}$ owych dwu statusów, wynikającym w sposób przyrodzony z samego faktu bycia człowiekiem.

Relatywizm kulturowy nakazuje właśnie ocenianie obcych nam praktyk $\mathrm{z}$ uwzględnieniem swoistego $\mathrm{w}$ ich środowisku systemu wartości czy sposobu myślenia o człowieku i jego miejscu w świecie. Zasadę tę rozumie i przyjmuje każdy etnolog (popularne ostatnio nazywanie go z anglosaska antropologiem jest też rezultatem zachwiania wartości, innej wprawdzie rangi i sfery odniesienia). Zgodnie z nią, ludzkości właściwy jest podstawowy zasób cech uniwersalnych, tzw. powszechników kulturowych, podczas gdy pozostałe kształtuja się w ramach odrebnych kultur jako wyuczone. Kultura jest systemem znaczeń krążących jako informacje, z których jedna nakazuje jej nosicielom uważać się za odrębną całość społeczną. Całość taką nazywamy etnosem, grupą etniczną, lub w skrócie kultura.

Istnieje także radykalna wersja relatywizmu, która odrzuca istnienie powszechników kulturowych i traktuje umysł ludzki jako tabula rasa, zapisywana dopiero w szkole życia, do jakiej uczeszczaja członkowie danej kultury. Skrajni relatywiści odrzucają możliwość porównywania kultur i poszukiwania łączących je cech wspólnych. Ich zdaniem byłby to zabieg niemoralny, prowadzący do hegemonizmu czy imperializmu kulturowego, przed którym chroni jedynie uznanie pełnej niezależności poszczególnych kultur. Takie stanowisko właściwe jest postmodernistom, nie będziemy się nim tu zajmowali jako niezbornym przejawem artyzmu naukowego.

Błędem jest więc kojarzenie relatywizmu z postmodernizmem i traktowanie go jako przejawu współczesnego upadku autorytetów i wartości. Relatywistami, zwłaszcza kulturowymi, byli twórcy cywilizacji antycznej, przede wszystkim Grecy. Starali się oni wystrzegać stereotypów kulturowych - co nie znaczy, że byli ich pozbawieni - zarówno w odniesieniu do ludów bliskich (np. Ateny - Sparta) jak i dalekich (Scyto-Sarmaci). Dzięki takiej postawie wykształcili w sobie tolerancje, ta bowiem bez relatywizmu nie istnieje. Odyseja, w pewnym stopniu także Iliada, dostarcza wielu po temu ilustracji. W ten sposób relatywizm kulturowy stał się jedną z wartości również cywilizacji zachodniej. Odrzucanie go na różnych etapach historii jest zwykłym przejawem ciągłej walki lub przekształceń w ramach poszczególnych systemów wartości.

2 Z. Bauman, „Dziura, nicość, utrapienie", Gazeta Wyborcza, 3-4 lipca 1999 r., s. H.
W Polsce o relatywizmie kulturowym nie pisze się, najwyżej wspomina o nim z nieodmiennie negatywnym mentorstwem. Rzadkie próby podjęcia tematu demonstrują zwykle nieznajomość rzeczy i formułują często kuriozalne tezy. Wystarczy przypomnieć poglądy J. A. Majcherka z $1997 \mathrm{roku}^{3}$. Z aprobatą należy odnotować ujawnioną ostatnia zmianę poglądów tego autora ${ }^{4}$. Warto więc czasami sięgnąć po nieobarczone moralizatorstwem opracowania zagraniczne, np. H. F. Steina ${ }^{5}$, i przytocznoną tam bibliografię.

W każdej swej wersji (tradycyjnej i postmodernistycznej) relatywizm egzemplifikuje ogólną prawdę, że człowiek jest stworzeniem wyjątkowym. Człowiek bowiem nie posiada jednej gatunkowej kultury i w nikłym tylko stopniu kieruje się zakodowanymi przez ewolucję instynktami. W początkach mijającego stulecia relatywiści stoczyli zwycięską na ogół (poza Związkiem Sowieckim) batalię, by nie wykorzeniać brutalnie w koloniach zwyczajów nieznanych białemu człowiekowi, których funkcji on sam nie rozumiał. Relatywizm był buntem przeciw tezie o jedności ludzkości, poddanej determinizmowi wspólnego procesu historycznego. W nowszych czasach relatywizm stał sie reakcja na nazizm, totalitaryzm, rasizm czy agresywny nacjonalizm, u podłoża których leżak) przekonanie, że odbieganie od „normy" oznacza bio-psychiczną lub społeczną podrzędność, którą należy radykalnie usunąć.

Ideologie niebezpieczne dla praktyki społecznej opierają się na przekonaniu, że jakaś grupa wybrana została przez Boga, historię lub imperatyw moralny do reprezentowania tego, co słuszne i co powinni zaakceptować wszyscy pozostali. Charakterystyczne, że taki pogląd dominował w dziejach Europy stale od wojen krzyżowych, przez podboje kolonialne, aż po prozelityzm systemu demokratycznego. Poza kregiem chrześcijańskim podobną, choć mniej dynamiczną aktywność, reprezentował islam. Nic więc dziwnego, że te dwa światy tak często wchodziły ze sobą w konflikt i owa konfrontacja nie należy jeszcze do przeszłości.

Relatywizm kulturowy nie ma nic wspólnego z moralnym, poza członem w nazwie. Zakazuje bowiem wartościowania porównywanych kultur i nie służy obronie ani gloryfikacji własnych wartości. Pomógł on etnologom odejść od postrzegania świata ludzkiego w porównawczych kategoriach na skali: doskonałość — prymitywizm, albo cywilizacja — barbarzyństwo. W tym sensie stal się narzędziem metodologicznym etnologii, co nie znaczy żeby uzyskał status powszechnej wskazówki o tym jak my-

${ }^{3}$ J. A. Majcherek, „Relatywizm a prawa człowieka", Rzeczpospolita, 3 grudnia 1997 r.

${ }^{4}$ J. A. Majcherek, „Poprawka z historii", Rzeczpospolita, 25-26 września 1999 r.

${ }^{5}$ H. F. Steina, „Cultural relativism", w: Encyclopedia of cultural anthropology, op. cit., s. 281-285 
Śleć o świecie. Stan powszechny polega na uproszczonym, by nie powiedzieć prymitywnym, odwoływaniu się do własnego etnocentrycznego wzorca. Charakteryzuje on zarówno ludzi prostych i wykształconych, rządzonych rządzących. Łatwo więc spotkać taką oto opinię, że Europejczykami są tylko niektórzy mieszkańcy kontynentu, do granicy wyznaczonej przez pewna rzekę. Naprzeciw takiemu poglądowi wytacza się ten, że owi rzekomo prawdziwi „Europejczycy" zatracili swe pierwotne wartości i winni je przywrócić naśladując obywateli tych pozostałych i lekceważonych krajów europejskich.

Podobnie rzecz się ma z tzw. wartościami azjatyckimi. Oczywiste jest, że Azjaci nie są regionalną ani gorszą odmianą Europejczyków. Truizmem byłoby przypominanie, że Azjaci przywiązani są do własnej kultury, bo dotyczy to wszystkich innych kręgów kulturowych. Przywiązanie nie musi jednak iść w parze $\mathrm{z}$ odrzucaniem wzorców importowanych. Najlepszym tego przykładem jest przyjęcie przez Indie zasad demokracji parlamentarnej. Było to działanie w pełni racjonalne, gdyż pozwoliło uniknąć wyboru spośród kilku znanych Indiom systemów rządzenia, nie dostosowanych do wymogów współczesności i oznaczających rozdrobnienie kraju. Wcześniej jednak Mahatma Gandhi odrzucił pozornie racjonalną walkę zbrojną o niepodległość, bliską europejskiej mentalności, i wybrał umiejscowiony dobrze we własne kulturze bierny opór. Toteż klęską dla niego był wybuch krwawych walk religijnych wskazujący na niejednoznaczność „tradycji azjatyckiej". Był też Gandhi przeciwnikiem okcydentalizacji kraju w sferze gospodarczej, jednak tu zwyciężyło stanowisko Nehru, lepiej rozumiejącego wyzwanie nowych czasów. Indie stały się pierwszym krajem azjatyckim, który świadomie i samodzielnie przystąpił do selekcji wartości odziedziczonych z własnej historii. Uczyniły to dla usprawnienia procesu adaptacji do życia w społeczności międzynarodowej.

Bardziej koniunkturalną postawę przyjęli rządzący w innych krajach, na co wskazuje powierzchowna demokratyzacja Japonii, Korei Południowej, Singapuru czy Tajwanu, gdzie klikowo-koteryjny sposób rządzenia towarzyszy demokratycznym wyborom (lub wciąż jeszcze towarzyszy). Trudnościom rozwojowym przypisuje się zbyt częsty nawrót do autorytarnego modelu (Filipiny, Indonezja, Malezja, Pakistan), niekiedy jeszcze na początku niepodległej państwowości. Podobne przyczyny zadecydowały o odrzuceniu reform Pahlaviego w Iranie czy o buncie tradycjonalistów w Turcji. Adaptacja do wzorów zachodnich nie zawsze wystarczająco silnie ugruntowała się społecznie, by przekształcić się w akulturację. Do wyjątków należy pełniejsza demokratyzacja Tajwanu w ostatnich latach, należy ją wszakże przypisac czynnikowi bio-politycznemu, mianowicie zejściu ze sceny starej generacj kuomintangowców wywodzących się z kontynentu.
Można przypuszczać, że dawne wzorce powracać będą także w przyszłości. świadczą o tym meandry w polityce wewnętrznej Chin, Indii, Indonezji czy Wietnamu. Nie dotyczy to wyłącznie Azji. Przywiązanie do kultury etnicznej, tłumione w postromantycznej Europie przez ideologię liberalną i komunistyczną, będzie nadal owocowało niepokojami i wybuchami. Azja będzie pod tym względem spokojniejsza (wyłączając konflik ty religijne), gdyż różnice etniczne nie były tein przedmiotem manipulacji politycznych; nie podejmowały ich ani ruchy modernistyczne, ani komunistyczne, wyjątkiem jest tylko Bliski Wschód, a zwłaszcza Turcja. Nacjonalizmy, szczególnie w opozycji do Zachodu, moga się jednak silnie ujawnić, chociaż najprawdopodobniej z ograniczoną agresywnością. Będzie tu miała wpływ wykształcona na Wschodzie zdolność negocjowania sprzeczności, chociaż i ona bywa niekiedy blokowana, o czym świadczy paroksyzm rewolucji kulturalnej w Chinach. Skłonność do negocjowania ma też swoje ograniczenia, jej sprawność zamyka się w granicach tego samego kręgu kulturowego, czego dowodem są rażące niezręczności Chińczyków w likwidowaniu konfliktów z Tybetańczykami czy Ujgurami. Generalnie jednak, kraje Azji rzadko przeżywały radykalne rewolucje przerywające ciągłość historii, poczucia wspólnoty i tradycji rozwoju myśli, filozofii i kultury, bowiem ani kolonializm, ani komunizm nie wprowadziły tu barier tak głębokich, jakich doświadczyła Europa. Jest to także ważna różnica determinująca stosunek do zmiany społecznej, jaką jest dla Azji propozycja pogodzenia się z koncepcją praw człowieka.

Propozycja ta ma dwie wady taktyczne: przedstawiana jest ultymatywnie wobec niektórych tylko krajów, ponadto opatruje się ją mianem uniwersalności, co oznacza bezwarunkowość i odrzucenie relatywizmu. Uniwersalizm praw człowieka jest iluzją wywodzącą się z etnocentryzmu cywilizacji zachodniej. Zachód staje się w ten sposób zwolennikiem pewnej uniwersalnej, w tym także „wschodniej" wartości - porzuconej już zresztą przez kraje azjatyckie, mianowicie centralnego pojmowania swego miejsca w świecie i płynącej stąd postawy hegemonistycznej. Polegała ona na przeciwstawieniu cywilizacji barbarzyństwu, czyli centrum wobec peryferii, jak w klasycznym chińskim obrazie świata. Nie oznacza to, że etnocentryzm w Azji zanikł, jest jednak na pewno słabszy niż demonstruje go Zachód, przynajmniej w kontekście międzynarodowym.

Deklaracja ONZ z 1948 r. nie mówi jeszcze o powszechności praw, jedynie $\mathrm{w}$ tytule sama przedstawia się jako powszechna, w intencji, że dokument zyska popularność. Z kolei większość systemów filozoficznych operowała koncepcją praw i obowiązków wynikających $\mathrm{z}$ uplasowania jednostki w społeczeństwie (status w rodzinie, przynależność do warstwy społecznej itp.) czy jej powinności wobec Stwórcy lub celu istnienia. Przynależność do gatunku ludzkiego jako kryterium miejsca i roli jednostki 
przemknęła w czasach antyku i umocniła się dopiero w epoce Oświecenia. Współczesna idea praw człowieka jest już manifestem politycznym, który miał służyć realizacji konkretnych zadań w świecie powojennym.

$\mathrm{Z}$ czasem uniwersalizm wartości zachodnich stal się ideologią powołaną zwłaszcza do zwalczania komunizmu, równie uniwersalnego w swoim zamyśle. Po zakończeniu zimnej wojny zwrócił się on przeciwko Chinom, ale w Azji przyjęty został jako oręż wymierzony w kultury i styl życia (nie koniecznie rządzenia) Wschodu w ogólności. Znalazł też opór wykraczający poza Chiny, ostro artykułowany, jak tego dowodzi wystapienie Mahathira bin Mohamada. To, że sama idea wykorzystywana jest do celów politycznych nie jest jeszcze powodem do jej dyskredytacji, jest tylko wskazówką do właściwego jej rozumienia w kontekście zastosowań. Należy zwłaszcza rozważyć na ile skutecznie posługuja się nia jej zwolennicy, a zwłaszcza dlaczego prowokują oni tak silny sprzeciw. Odpowiedź zdaje się leżeć właśnie w połączeniu koncepcji uniwersalności z konkretnym geopolitycznym rodowodem samego pakietu praw człowieka.

Zestawienie to wywołuje podejrzenia uwarunkowane ciągle pamiętanymi podbojami kolonialnymi, że oto z tego samego źródła płynie wezwanie do podporządkowania się ideom, których realizacja przyniesie korzyści jej autorom raczej niż reszcie świata. Nie została zapomniana walka Zachodu o prawo do otwartych mórz i do wolnego handlu połączonego $\mathrm{z}$ prawem do interwencji w jego obronie. Przedstawiano je wówczas także jako prawo o znaczeniu powszechnym.

Azja stała się bastionem oporu nie tyle przeciw samym prawom człowieka, co ich natarczywemu narzucaniu. Fakt ten jest godzien uwagi, bowiem we współczesnym świecie ten zwłaszcza kontynent ma potencjał intelektualny odpowiedni po temu, by taki opór stawić. Wzmacnia go świadomość walorów swojej historii politycznej i kulturalnej w skali tak całego kontynentu, jak i jego fragmentów. Nie bez znaczenia jest też utrzymujace się poczucie upokorzenia presją kolonializmu, mimo - a może dlatego właśnie — że kraje Azji były nierzadko w stanie zmobilizować się do skutecznej walki.

Koncepcja wartości azjatyckich, choć nie wolna od niekonsekwencji, ma dużą siłę przekonywania, przede wszystkim dla samych mieszkańców Azji. Kwestionuje ona wadliwą logicznie ideę powszechności praw człowieka i zadaje proste pytanie: jeśli prawa te są uniwersalne, to dlaczego należy uczyć innych (tzn. Azjatów) tego, do czego sami powinni byli dojść na jakimś etapie swojej historii. Jeśli zaś ten etap jeszcze nie nadszedł, to nie należy go sztucznie przyspieszać. Skoro bowiem Zachód prawa te uświadomił sobie, wyodrębnił je i skodyfikował dopiero przed pół wiekiem', to najprawdopodobniej są one nie tyle powszechne, co adekwatne do czasu, doświadczeń historycznych i potrzeb tej właśnie strefy geopolitycznej.
Mamy tu więc do czynienia z czymś w rodzaju relatywizmu historycznego, czyli z dialektycznym rozumieniem praw człowieka. Pytanie jest zasadne mimo tego, że to co proponuje Zachód ma swoje walory.

Kampania na rzecz tych praw ma zdaniem Azjatów wyraźne motywy polityczne - zmierza do zastosowania presji ideologicznej celem dzielenia kontynentu poprzez nagradzanie i karanie jego państw, czy raczej rzadów. Podobne stanowisko nie jest obce także części opinii zachodniej, która dostrzega w nim ustawianie się Europy na pozycji kontrkultury wobec kultur azjatyckich. Takie ujęcie cechuje zwłaszcza kontestująca młodzież spod znaku Nowej Ery, przenikniętej w sporej mierze kultem cywilizacji wschodnich. Również na tym gruncie pojawia się teza, że ekspansja ideologiczna Zachodu jest przejawem hipokryzji z powodu jej wybiórczości i na dodatek nieskuteczna, wywołuje bowiem otwarty sprzeciw (Iran, Chiny, Indie, świat arabski). Gorączka, która tej ekspansji towarzyszy ma przypominać stan kryzysowy różnych imperiów w przeddzień ich upadku ${ }^{6}$.

Silne są także opinie przeciwstawne. Pod hasłem praw człowieka działają liczne organizacje i osoby indywidualne (także tutaj dominuje młodzież) w czymś, co stało się już międzynarodowym ruchem społecznym z własna ideologią. Przyjmuje ona niekiedy formy bezkompromisowe w wykonaniu nazbyt gorliwych zwolenników posuwających się do publicznego głoszenia nieuczciwych zarzutów zarówno w sferze faktów, jak też personalnie wobec autorów niepodzielanych opinii ${ }^{7}$.

Niezależnie od swych uwikłań politycznych idea praw człowieka jest także manifestem etycznym i z tego względu ma dużą siłę oddziaływania. W tym aspekcie akceptuje ją premier Mahathir $z$ jednym w zasadzie zastrzeżeniem. Nie wyobraża on sobie mianowicie, by na Wschodzie pogodzono się z priorytetem jednostki wobec społeczeństwa i to nie tylko w krajach kręgu konfucjańskiego. Przemilcza natomiast kwestię główną w stanowisku Zachodu i naczelna w praktyce organizacji obserwujacych stan praw człowieka. Jest nią daleko posunięta arbitralność władz państwowych wobec osób znajdujących się w konflikcie z prawem oraz rozciągliwość definicji owego konfliktu. Problemy tej natury istnieją w wielu krajach, także azjatyckich, chociaż do polskiej opinii docierają niemal jedynie informacje dotyczące Chin.

Stanowisko Mahathira nie rozstrzyga niczego w dyskusji, zwłaszcza w kontekście nasilonych ostatnio represji wobec wewnettrznej opozycji kierowanej przez jego byłego zastępcę Anwara Ibrahima. Zacietrzewienie $\mathrm{w}$ tej walce doprowadziło do zaostrzenia stanowiska i w przemówieniu otwierającym światową konferencję prawników we wrześniu 1999 r. Ma-

${ }^{6} \mathrm{R}$ Kennedy, Mocarstwa świata. Narodziny, rozkwit, upadek, KiW, Warszawa 1994.

${ }^{7}$ Np. K. Łoziński, „Nie torturuj i pozostań sobą", Gazeta Wyborcza, 20-21 marca 1999. 
hathir oświadczył, że prawa zbiorowe narodów mają bezwzględne pierwszeństwo przed prawami jednostki. Wyraźniej też sformułował swe wcześniejsze zarzuty pod adresem światowej finansjery, odpowiedzialnej jakoby za azjatycki kryzys gospodarczy, co również jego zdaniem jest gwałtem na prawach człowieka. Koniunkturalizm interpretacji tych praw jest nie mniejszy niż $\mathrm{w}$ przypadku ich zachodnich orędowników, a $\mathrm{z}$ pewnością mnie skrywany. Można tu więc mówić o relatywizmie moralnym po obu stronach barykady.

Przywódcy Chin nie angażują się zbytnio w polemikę, skoro wyręczają ich w tym względzie politycy Malezji i Singapuru. Można sobie wyobrazić wylansowanie konkurencyjnej, azjatyckiej koncepcji praw człowieka i próby tego rodzaju były czynione (porównaj priorytet miski ryżu i przyodziewku). Miały one jednak charakter ograniczony w czasie jako etap wstepny, po którym miałoby nastąpić przyjęcie szerszego zestawu praw zachodnich chyba jednak nie w pełnym komplecie. Te ostatnie bowiem obrastają w uzupełnienia i postulaty ideologiczne przydające całej koncepcji, lub jej fragmentom, postać utopii, szlachetnej w zamyśle ale nie dostosowanej do realiów żadnego miejsca.

Systemy wartości nie są dane raz na zawsze i zmieniają się wraz ze zmianami w samej kulturze. Również koncepcja praw człowieka przechodziła zmiany w krótkim okresie swego funkcjonowania, przekształcał się też azjatycki system wartości. Nie należy więc wykluczać jego konwergencji z zachodnim, zwłaszcza jeśli bedzie to obiecywało lepsze funkcjonowanie społeczeństw azjatyckich. Ich elity bowiem sa nie mniej pragmatyczne od zachodnich. Przyjmując za rzecz oczywistą swoistość odrębnych kultur, nie możemy zakładać ich niezmiennego trwania w czasie, czyli absolutyzować ich tradycjonalizmu. Popadlibyśmy wówczas w dogmatyczny relatywizm, odmawiający społeczeństwom zdolności rozwoju i przypisujący im negatywne standardy.

Dopóki jednak trwa owa swoistość, czyli ma ona licznych zwolenników, nie należy dziwić się, że rozwiązania importowane bẹa budziły nieufność lub zostaną odrzucone. Żadna władza nie zdecyduje się na lekceważenie wartości zinternalizowanych przez społeczeństwo, jest to bowiem także wymóg demokracji, a prócz tego wymóg utrzymania władzy. Wbrew twierdzeniom idealistów z naszego kręgu cywilizacyjnego, społeczeństwa wschodnie nie marzą o porzuceniu utartych wzorców życiowych. Walkę z konserwatyzmem, tym masowym i ulokowanym w strukturach władzy, podejmuja jednostki Wszelkie zmiany w świadomości i praktyce społecznej winny więc odbywać się w trybie ewolucyjnym, a ich przyspieszenie mogą warunkować czynniki wewnetrzne dla tych społeczeństw, takie jak industrializacja i rozwój gospodarki rynkowej, chociaż przykład Singapuru czy Hongkongu dowodzi, że nie są one wystarczające.
W żadnym z krajów azjatyckich sytuacja nie jest obecnie na tyle kryzysowa, by wymagała głębokiej i sterowanej odgórnie reformy społecznej. Ich historia uczy, że w potrzebie są one zdolne do takiej reformy, mimo jej poważnych kosztów (Chiny w czasach nowożytnych przeżyły ich kilka). Ci więc, którym leży na sercu sprawa popularyzacji praw człowieka, powinni znajdować otuchę w małych krokach podejmowanych przez krytykowane rządy, miast niecierpliwić się, że nie dokonują one w tym względzie rewolucji. 